\title{
SOME OBSERVATIONS ON THE GLACIOLOGY OF THE RUWENZORI RANGE
}

\author{
By I. R. Menzies
}

IN an article in this Journal * on the equatorial glaciers of East Africa Lieutenant-Commander Spink described the Ruwenzori range as a non-volcanic chain of peaks extending about 70 miles (I 2 km.) along the Belgian Congo-Uganda border in a north-north-easterly direction.

I traversed this range in December 1949 as a member of a small party led by Mr. Ashley Greenwood. We followed the route shown in Fig. I below. We had but little time to spare for detailed study, but the paucity of information on this area prompts me to offer these few observations in the hope that they may fill in some gaps and initiate a fuller enquiry.

The largest glaciated area visited was the Stanley Plateau. This caps Mt. Stanley and through it protrude several peaks-Margherita, the highest point of the whole range, rising approximately to $16,794 \mathrm{ft}$. (5 I $19 \mathrm{~m}$.), Alexandra ( $16,749 \mathrm{ft}$.), Elena ( $16,3^{8}{ }_{5} \mathrm{ft}$.), Savoia (I6,42 r ft.).

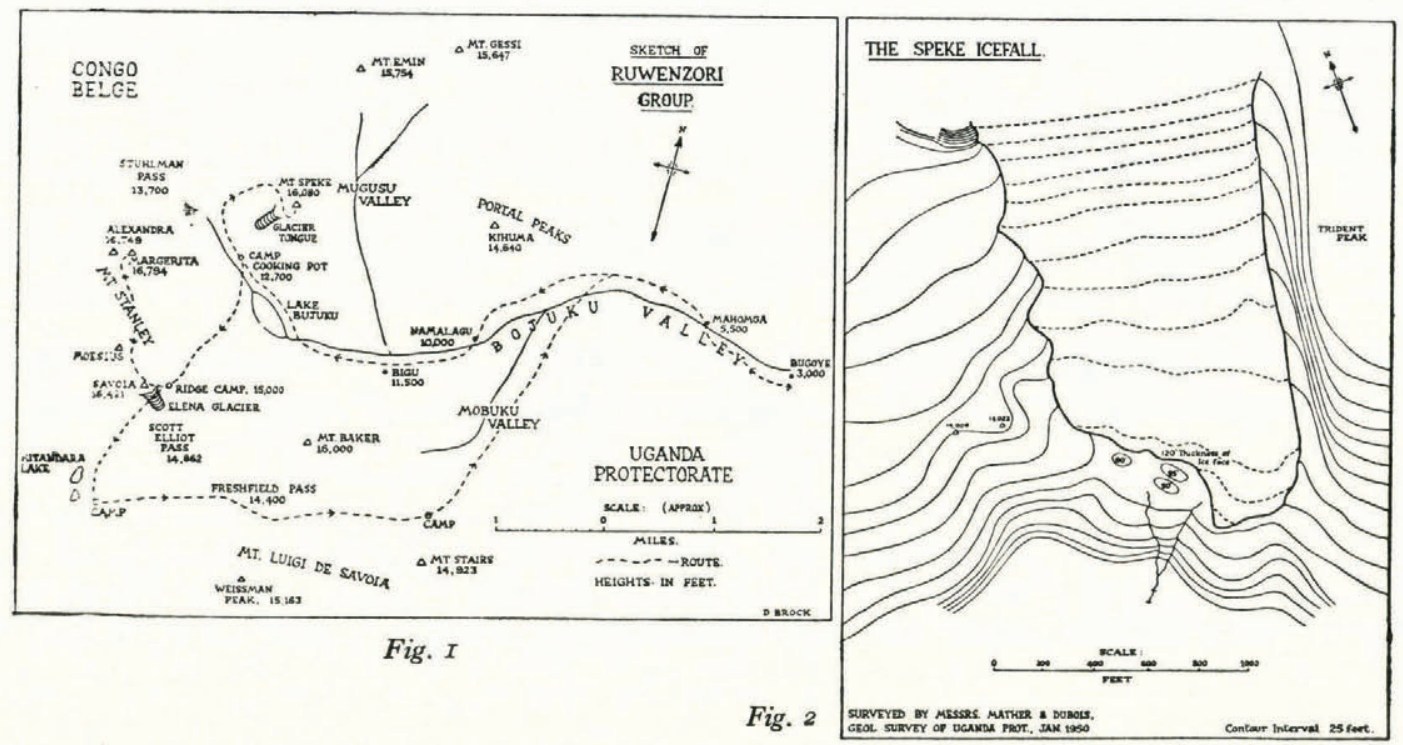

The plateau is about a mile long and falls slightly towards the foot of Margherita. Its mean height is about $16,000 \mathrm{ft}$. $(4877 \mathrm{~m}$.). We ascended to it by the Elena Glacier tongue.

No powder snow lay on the ice although much rain had fallen at lower levels during the previous week. The firn was fairly consolidated, no doubt because of the large diurnal range. A remarkable point is that there was never more than a gentle breeze during our stay and this, I believe, is the normal state of affairs.

I did not see a dirt cone, thrust plane, perched block, pot-hole, surface stream nor any nieve pentente on any glacier. The glaciers are only moderately crevassed and the run-off streams, although examined at all times of day, were almost free of rock flour.

Where cornices were seen they were not of the usual alpine type and suggested no prevalent wind direction. During three nights at Ridge Camp at $15,000 \mathrm{ft}$. $(457 \mathrm{I} \mathrm{m}$.), beside the Elena Glacier the temperature never fell below $28^{\circ} \mathrm{F} .\left(-2 \cdot 2^{\circ} \mathrm{C}\right.$.) and on the first night only reached freezing point. The snow on the plateau lost crust at about 9:30 a.m.

\footnotetext{
- Fournal of Glaciology, Vol. 1, No. 5, 1945, p. 277-81.
} 
A close examination was made of a glacier tongue $1000 \mathrm{ft} .(305 \mathrm{~m}$.) above the East African Mountaineering Club hut at Bujuku. This flows down from Mt. Speke. Here we were joined by Messrs. O. K. Mather and G. Du Bois of the Geological Survey, who by permission of its Director, Dr. K. A. Davies, were enabled to visit this area and map the tongue (see Fig. 2, p. $5^{\text {II }}$ ).

A beacon was set up so that annual measurements may be made. The glacier snout lies at about $14,000 \mathrm{ft}$. $(4267 \mathrm{~m}$.) in a deep gulley whose smooth sides display an obvious and rapid retreat. Vegetation has not yet sprung up in the abandoned area which extends to an altitude of 13,000 ft. (3962 m.).

Large areas were devoid of firn and showed layers of dirty ice, the dirt probably consisting of wind-blown dust and the ash from the innumerable forest fires which are lit in the valleys every hot season. Only a few stones were held in the ice and there is no moraine at the present glacier foot although a fairly large one exists $500 \mathrm{ft}$. $\left(1_{52} \mathrm{~m}\right.$.) lower down. Still lower very large ancient moraires are in evidence.

I was able to crawl right under and inside the ice at the centre of the snout. There were no signs of plucking of the rock bed. The roof of this ice cave was $5 \mathrm{ft}$. ( $(\mathrm{r} \cdot 5 \mathrm{~m}$.) above me with corrugations transverse to the line of flow at $4 \mathrm{ft}$. intervals. The crystals here measured up to $3.0 \times 0.5 \mathrm{~cm}$. and there seemed to be a tendency for them to lie vertical to the line of flow. At the side of the tongue they were smaller (about $1.0 \mathrm{~cm} . \times 2 \mathrm{~mm}$.) and I had the impression that they lay more or less parallel to the line of flow. There were bands of smaller crystals and their significance is obscure. They cannot be annual bands as there is no distinct winter-summer cycle.

Access to, and examination of, the Elena Glacier was difficult because of ice falling from the hanging glacier above it. The snout could not be reached, but beacons were set up for annual measurements. These may be found by bearing $195^{\circ}$ from Ridge Camp and walking for fifteen minutes. The snout of this glacier terminates at $14,800 \mathrm{ft}$. ( $45 \mathrm{II} \mathrm{m}$.) in a deep unvegetated groove. There is no terminal moraine and its stream is clear of detritus. This is true of all the Ruwenzori glacier streams and one never sees the turbid, opaque water common to alpine streams of similar type.

At some $200 \mathrm{ft}$. (6I m.) above the snout I entered a cleft by a rock outcrop. I found only dense, consolidated firn. The crystals were of millimetre size. Ablation caused bands to stand out like fins of an air-cooled cylinder. They contained much dirt but again only of such size as could be wind-blown. Again there was no evidence of plucking of the rock bed and no boulders or detritus could be seen in the snout of this glacier.

I could find no true glacier ice above the snout nor any sign of present glacial action, and this would seem to show that the conditions now existing are not quite usual. Investigation should be continued at other times of year and more frequently. Valuable work could be performed by a properly equipped party camping on the Stanley Plateau and working over a much longer period than was possible for us.

MS. received 8 May $195^{\circ}$

\section{THE LARSEN SHELF ICE}

Discussion of the paper by Mr. D. Mason read at a Meeting of the Society on 77 November 1949. (Fournal of Glaciology, Vol. I, No. 8, 1950, p. 409-13.)

The Chairman (Professor Gordon Manley) opened the meeting for discussion.

Professor S. E. Hollingworth (University College, London) raised the question of the terminology of the various types of shelf ice and expressed the hope that at this stage of their investigation names and definitions should be descriptive rather than general. 